\title{
BIOTECNOLOGIAS, CLONES E QUIMERAS SOB CONTROLE SOCIAL missão urgente para a divulgação científica
}

\author{
Marcelo Leite \\ Editor de Ciência da Folha de S.Paulo, jornal do qual foi também ombudsman, e autor do livro Folha Explica: Os alimentos transgênicos
}

\begin{abstract}
Resumo: A polêmica no Brasil sobre a regulamentação dos alimentos transgênicos costuma ser interpretada à luz da dicotomia de atitudes entre Estados Unidos e Europa. Pesquisas de opinião recentes revelam, no entanto, um quadro muito mais matizado, tornando essas categorias em grande medida irrelevantes para a compreensão da controvérsia brasileira. A divulgação científica pela imprensa pode contribuir para aumentar o grau de objetividade desse debate, mas se encontra tolhida por deficiências diversas, do baixo grau de informação científica do público à sua própria incapacidade de problematizar a apresentação ideológica da biotecnologia.
\end{abstract}

Palavras-chave: biotecnologia; alimentos transgênicos.

1 engenharia genética e outras biotecnologias ocupam hoje o lugar central na representação social da ciência, a ponto de se tornar corrente a opinião de que este século - ou talvez o próximo - ficará conhecido como o Século da Biotecnologia. Ela aparece para o público como o próprio paradigma da tecnociência, o estágio atual da pesquisa que, diferentemente do século 19 , faz da investigação científica o motor mesmo do avanço técnico, deitando por terra o sistema de dicotomias que dava solidez à sua representação tradicional: ciência $v s$. técnica; natureza vs. sociedade; biologia vs. tecnologia. Uma ciência que não se limita a explicar coisas, mas já o faz para modificá-las e mobilizá-las no processo de produção.

O potencial que dissolve valores e representações encerrado na engenharia genética parece inesgotável. Para a marcha lenta da esfera pública, os anos 80 e 90 estão repletos de controvérsias públicas e jurídicas desencadeadas por movimentos bruscos e imprevisíveis, oriundos dos laboratórios de pesquisa e das "companhias de ciências da vida", das quais os laboratórios dependem em escala crescente. Do patenteamento de seres vivos, inaugurado nos Estados Unidos em 1980 com a decisão da Suprema Corte em favor de Ananda Chakrabarty e da General Electric, à presente disputa jurídico-regulatória em torno do cultivo de alimentos transgênicos no Brasil e na Europa, a genética se revelou em duas décadas uma ma- triz perturbadora de hábitos e convenções em vários domínios da vida social: economia, direito, saúde, ambiente, reprodução e alimentação. Mais que a capacidade de manipular as letras do código hereditário de plantas, animais e homens, a engenharia genética se notabiliza pelo poder de pôr em crise representações basilares sobre o que seja humano e natural, impondo ao mundo seus clones e quimeras (como pés de milho que produzem hormônio de crescimento humano e cabras que secretam proteínas da teia de aranha no próprio leite).

Não parece estranho, portanto, que surjam do público as reações mais adversas diante da admirável nova biologia. A repulsa aos alimentos transgênicos parece ser apenas o topo visível de uma profunda desconfiança, alimentada pela percepção de que a fronteira entre natureza e cultura - que, diga-se, sempre foi móvel e historicamente determinada - está sendo retraçada não tanto sob os ditames de uma ciência pura e desinteressada, mas sim, predominantemente, sob interesses daquilo que se poderia denominar "complexo industrial-biotecnológico", a exemplo do complexo industrial-militar que movia economia e pesquisa nos anos 60 e 70 (além de toda uma literatura de crítica sociológica). Defensores das biotecnologias (entre eles autoridades reguladoras que deveriam manter maior distanciamento), no entanto, tendem a atribuir a resistência da opinião pública à ignorância, o que a tornaria vulnerável a argumentos ditos "emocionais" esgrimi- 
dos por organizações ambientalistas e de consumidores, supostamente mais interessadas em confundir do que explicar.

Sem negar o papel exercido pela falta generalizada de conhecimentos científicos básicos, em particular num país como o Brasil, este trabalho tem por objetivo colocar em dúvida essa visão um tanto míope e indicá-la como uma das importantes razões pelas quais a biotecnologia agrícola encontra tanta dificuldade para tornar-se aceitável para o público, seja ele brasileiro, japonês, europeu ou mesmo norte-americano. A divulgação científica tem papel relevante a cumprir na abertura de um terreno comum de neutralidade e racionalidade entre os campos opostos e extremados, mas não pode por si só gerar o consenso necessário, pelas limitações institucionais da imprensa e dos centros produtores de pesquisa (que não são órgãos políticos de representação), ou porque a própria imprensa se encontra prisioneira de mecanismos de reprodução do que caberia chamar de ideologia cientificista. Esses temas serão discutidos com base na polêmica dos já mencionados alimentos transgênicos e no entusiasmo com o Projeto Genoma Humano.

\section{TRANSGÊNICOS: MAIS INFORMAÇÃO NÃO GARANTE MAIS APOIO}

A descoberta de que os alimentos transgênicos estavam perto de chegar ao mercado acordou a opinião pública brasileira no segundo semestre de 1998. A perspectiva de passar a ingerir vegetais geneticamente modificados despertou vagos fantasmas, semelhantes aos da energia nuclear: uma tecnologia incompreensível, fora de controle público e capaz de pôr em circulação ameaças invisíveis contra a saúde humana e o ambiente. A polêmica chegava com certo atraso, embora mais rapidamente do que aos Estados Unidos, onde só se tornou tema de debate este ano. Enquanto isso, na Europa e na Ásia, os transgênicos literalmente pegavam fogo, com militantes ambientalistas incendiando campos cultivados com variedades de organismos geneticamente modificados (os famigerados OGMs), plantas "engenheiradas" para se tornarem resistentes a insetos ou herbicidas. Diante da forte reação pública, a União Européia (que havia autorizado a importação e o processamento da soja transgênica em 1996) havia decidido, já em maio de 1998, introduzir regras para rotular alguns produtos contendo soja ou milho geneticamente alterados. Nos Estados Unidos, em contraste, culturas transgênicas já estavam aprovadas e em plantio desde
1995, sem qualquer imposição de rótulos ou segregação de produtos.

No Brasil, desde junho de 1998 a Comissão Técnica Nacional de Biossegurança (CTNBio) examinava um pedido de licença da empresa Monsanto para comercializar a soja geneticamente modificada Roundup Ready, uma variedade resistente ao herbicida Roundup, da própria Monsanto. Em 24 de setembro do mesmo ano, apesar de uma liminar sustando o plantio, obtida pelo Instituto Brasileiro de Defesa do Consumidor (Idec) e pela organização ambientalista Greenpeace, a CTNBio reiterou sua autorização, deliberando que nada haveria a temer do ponto de vista da biossegurança e deixando outros aspectos de licenciamento a critério do Ministério da Agricultura. Era a primeira licença que a Comissão concedia para cultivo em escala comercial, ainda que prevendo um monitoramento sob sua égide, e ela serviu de rastilho para uma saraivada de recursos e liminares. Com o concurso da Justiça, que vem sistematicamente tomando decisões contrárias à CTNBio e à Monsanto, o Brasil ainda se recusa a seguir o caminho da Argentina, país que aprovara a novidade da biotecnologia sem pestanejar e hoje conta com aproximadamente $80 \%$ de sua safra geneticamente modificada, mais que os Estados Unidos (mais de 50\%) e o Canadá (cerca de 10\%).

$\mathrm{O}$ contraste entre os paradigmas norte-americano e europeu, sobre a intensidade regulatória e a aceitação pelo público, tem sido empregado com freqüência para tentar explicar - e influenciar - o panorama brasileiro. Tal dicotomia padece, entretanto, de um defeito crucial: falta-lhe o elemento dinâmico, ou seja, ela pouco tem a dizer sobre a evolução dessas tendências de um e de outro lado do Atlântico Norte. Aqueles que se comprazem em anotar uma atitude mais favorável dos reguladores e do público norte-americano aos alimentos transgênicos podem deixar escapar que esse comportamento parece estar em transformação, em prejuízo das culturas geneticamente modificadas. Por outro lado, engana-se provavelmente quem concluir que europeus têm uma opinião contrária, por princípio, às manipulações genéticas, ou que só eles vêem com desconfiança o desempenho de seus representantes no Estado encarregados de zelar pela saúde humana e do ambiente na introdução de novos alimentos.

Um quadro muito mais matizado emerge, na realidade de uma série de quatro artigos baseados em extensas sondagens de opinião pública que foi publicada recentemente pela revista especializada Nature Biotechnology (2000:935-947). 
No caso dos Estados Unidos (Priest, 2000), apesar de haver ainda maioria de entrevistados (59\%) favoráveis à biotecnologia, observa-se uma contínua erosão desse apoio. Segundo o levantamento do International Food Information Council (IFIC) citado no artigo, ele era de $63 \%$ em outubro de 1999 , de $75 \%$ seis meses antes e de $78 \%$ em 1997. Em seu próprio levantamento, a autora do trabalho na Nature Biotechnology encontrou 52,8\% com uma visão positiva dos desenvolvimentos na biotecnologia, mas chama a atenção para o contingente nada desprezível $(30,1 \%)$ daqueles que acreditam na possibilidade de que ela "torne as coisas piores". Somente a energia nuclear, entre os campos tecnológicos submetidos à avaliação dos entrevistados, obtém tal grau de desconfiança (Gráfico 1).

Também parece carecer de fundamento empírico, a julgar pelo perfil de opiniões coletadas, a convicção de que níveis maiores de informação científica ou de escolaridade, assim como a dos norte-americanos, têm alto grau de confiança nas autoridades governamentais reguladoras (só 39,5\% disseram que elas estavam fazendo um bom trabalho em relação à biotecnologia, o índice mais reduzido entre as várias instituições mencionadas na pesquisa, menos até do que a imprensa, com 44,4\%).

A conclusão é que, mesmo na pátria da biotecnologia, ela ainda poderá enfrentar tempos difíceis: "O quadro
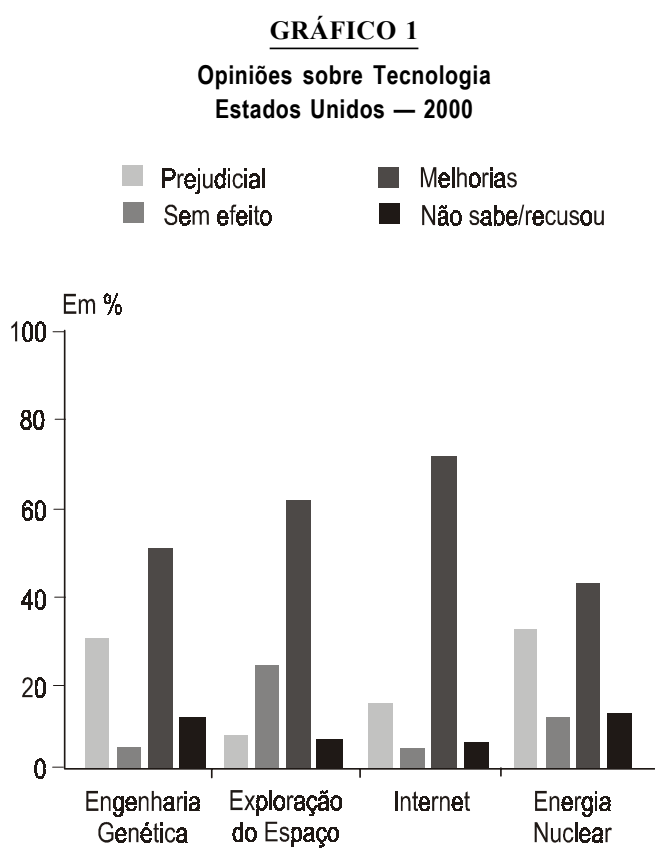

Fonte: Nature Biotechnology (2000:939). apresentado por esses dados é o de um público algo dividido, nos Estados Unidos. Embora ao se olhar apenas para números acumulados seja possível argumentar que os Estados Unidos permanecem positivos sobre a biotecnologia, de uma maneira geral, também não é incomum a resistência. (...) o prognóstico de um debate público mais acalorado sobre essas questões, nos Estados Unidos, parece consistente com tais resultados" (Priest, 2000:942).

$\mathrm{O}$ artigo que relata a sondagem realizada no Canadá chega a conclusões similares quanto ao mito de que uma atitude negativa em relação à biotecnologia seja fruto, necessariamente, de desinformação: "Há controvérsia sobre o papel da 'informação científica' (scientific literacy) em julgamentos sobre ciência e tecnologia; alguns sustentam que ela leva a julgamentos positivos, enquanto outros sugerem o contrário. Os resultados deste estudo sugerem que a posse de conhecimento sobre genética nem mesmo participa desse cálculo - um ponto importante a ter em mente no contexto da crença comum de que elevar a informação vá render apoio", diz a autora. E acrescenta: "Ao fiar-se numa 'avaliação de risco com base científica' estreitamente definida, as instituições reguladoras existentes tendem a descartar peremptoriamente essas preocupações mais amplas do público e/ou a encontrar dificuldades para enfrentá-las quando emergem" (Einsiedel, 2000:944).

Pesquisas de opinião coordenadas em 16 países da União Européia, entre 1993 e 1999, revelam igualmente, como seria de se esperar, uma queda continuada no otimismo quanto à biotecnologia em geral. De $53 \%$ otimistas em 1993, passou-se a 50\%, em 1996, e a 46\%, em 1999 (Gaskell et alii, 2000).

Os dados mais relevantes, contudo, provêm de uma distinção antes insuspeitada entre biotecnologia aplicada à agricultura e biotecnologia aplicada à alimentação (diferenciação de todo cabível, uma vez que plantas transgênicas podem ser criadas para produzir substâncias de interesse, vale dizer, para que funcionem como biorreatores, secretando em suas células proteínas como hormônios humanos, ou que sirvam para a produção de plásticos, por exemplo). Convidados a julgar sete aplicações biotecnológicas (testes genéticos pré-natais, terapias genéticas, biorremediação ambiental, clonagem de células humanas, clonagem de animais, culturas transgênicas e alimentos transgênicos) sob quatro parâmetros (utilidade, risco, aceitabilidade e apoio), os entrevistados fizeram surgir um padrão inusitado, em que a biotecnologia agrícola aparece sob uma luz bem mais favorável que os alimentos transgênicos em si: enquanto estes são percebi- 


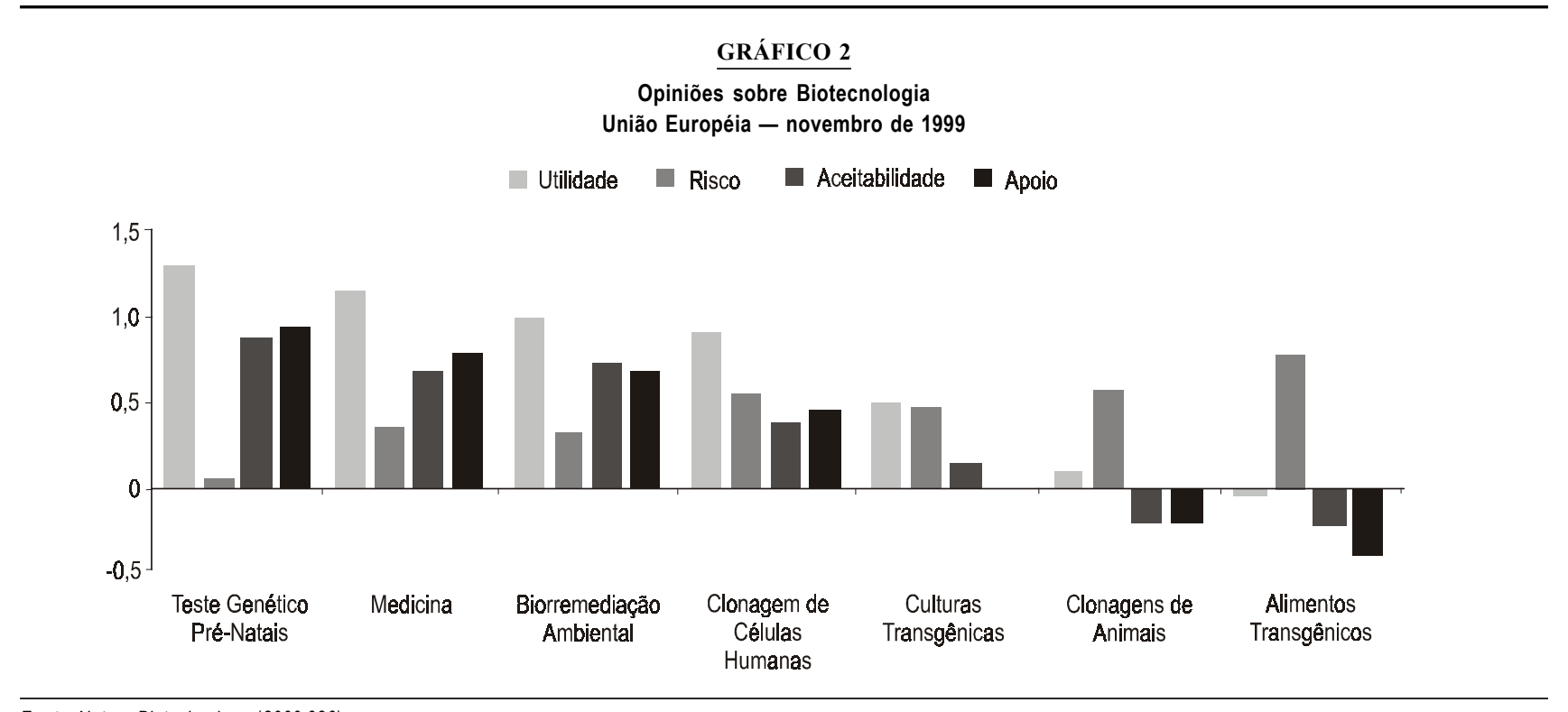

Fonte: Nature Biotechnology (2000:936).

dos como pouco úteis, muito arriscados, pouco aceitáveis e indignos de apoio, aquela tem sua utilidade concebida como ligeiramente superior ao risco que engendra e algo aceitável, ainda que não chegue a despertar apoio (Gráfico 2). Dissociação comparável ocorre entre a clonagem de células embrionárias humanas (células-tronco) para fins terapêuticos, tida como aceitável em razão de potenciais benefícios (como a esperada síntese de órgãos para transplante em laboratório ou o tratamento de doenças degenerativas), e a clonagem de animais inteiros, considerada inaceitável.

Para os autores do trabalho, esses dados indicam que a imagem mais problemática da biotecnologia na Europa parece não decorrer de uma objeção de princípio, apenas e tão-somente moral, mas sim de uma ponderação de riscos e benefícios, em cada caso: "O apoio maior para clonagem de células e tecidos humanos, em relação à clonagem de animais, sugere que considerações morais se referem especificamente a aplicações particulares e não necessariamente às técnicas de biologia molecular subjacentes. Mais ainda, a maior oposição a alimentos transgênicos, em comparação com culturas transgênicas, sugere que, para o público, a segurança alimentar pesa mais que preocupações ambientais" (Gaskell et alii, 2000:935).

Recapitulando: é mais que questionável a dicotomia que opõe um consenso norte-americano em favor da biotecnologia a um consenso europeu contra ela, assim como interpretações de fundo culturalista, segundo as quais, por um lado, os Estados Unidos seriam mais pragmáticos, tecnófilos e confiantes em suas autoridades reguladoras, e a Europa, por outro, mais filosófica, tecnofóbica e desconfiada de seus representantes (por conta dos traumas como nos casos de contaminação de alimentos por dioxinas e pela chamada "doença da vaca louca", ou BSE). Isso para não falar do contra-senso evidente de imaginar que o público europeu seja mais desinformado e manipulável por organizações não-governamentais ambientalistas do que o norteamericano, ou que tudo se resume a uma conspiração protecionista, um capítulo a mais na guerra tarifária movida por um continente que não dispõe da tecnologia OGM. Enquanto essas categorias forem aplicadas para tentar explicar ou resolver o amarrado debate brasileiro sobre a biotecnologia agrícola, ora estacionado nas barras da Justiça, pouco se avançará. É tarefa do jornalismo científico, além de fornecer as informações básicas para entender a tecnologia, livrar-se ele mesmo dessas imagens simplificadoras e oferecer ao público um quadro mais matizado e próximo da complexidade social e política da questão.

\section{O PROJETO GENOMA E SUA IDEOLOGIA}

No centro de gravidade da biologização da tecnologia mencionada no início deste artigo encontra-se o Projeto Genoma Humano (PGH), lançado em 1986. O projeto tem sido, na última década, a parte mais visível da pesquisa genética para o grande público, pois se tornou notícia obrigatória ao introduzir a biologia no domínio da Grande Ciência (Big Science), com projetos de pesquisa - como Manhattan e Apollo - em que os cientistas mobilizados se contam em milhares e os dólares despendidos, em bi- 
lhões. Não faltam para a mística do Genoma nem mesmo os temperos ideológicos da concorrência e da dicotomia: estatismo $v s$. privatização, adicionados à polêmica em maio de 1998 com a criação da Celera, uma empresa com capital de US\$ 200 milhões resultante da associação entre a Perkin-Elmer (fabricante de equipamentos para laboratórios) e Craig Venter, cientista que se notabilizou no início dos anos 90, tanto pela invenção de técnicas para o seqüenciamento automático de DNA quanto por multiplicar pedidos de patentes para genes humanos. No final de junho de 2000, Venter protagonizou, com o presidente Bill Clinton, o premiê Tony Blair e o chefe norte-americano do PGH oficial, Francis Collins, o midiático anúncio do seqüenciamento completo do código genético humano (embora a esperada publicação conjunta do "mapa" genômico só deva acontecer nos próximos meses).

Apesar do nome Projeto Genoma Humano, que parece restringir a empreitada à espécie humana, estão nela incluídos também os seqüenciamentos de organismos de outras espécies, até como etapas preparatórias para alcançar o que já se chamou de Santo Graal da biologia. Esses esforços permitiram decifrar dois primeiros genomas de animais multicelulares, o do verme $C$. elegans (dezembro de 1998) e o da mosca Drosophila melanogaster (julho de 1999). Até no Brasil há esforços genômicos em andamento, dois deles com a alça de mira voltada para dividendos da biotecnologia na citricultura: os das bactérias causadoras das doenças do amarelinho da laranja (Xylella fastidiosa) - notabilizado em julho pela publicação de um artigo científico na prestigiada revista Nature, que o destacou em sua capa - e do cancro cítrico (Xanthomonas citri).

O verdadeiro esteio do Projeto Genoma Humano junto à opinião pública é uma ficção muitas vezes realimentada pelo jornalismo de ciência: a idéia de que o seqüenciamento completo das bases nitrogenadas do genoma de uma espécie dará acesso à sua "essência". No caso do homem, ao que significaria ser humano e, assim, à chave de todas as doenças, até mesmo do comportamento e de seus distúrbios. Sem esse gênero de operação simbólica, o Projeto Genoma dificilmente amealharia as verbas milionárias de que necessita. A sobrevivência do programa depende da sobrevivência da concepção reducionista e determinista dos genes como átomos plenipotentes da natureza, inclusive da humana.

O núcleo duro dessa ideologia genética é o ácido desoxirribonucléico (DNA), molécula em forma de dupla hélice modelada em 1953 por James Watson e Francis
Crick que suporta o código-fonte dos genes. Suas características fundamentais seriam a capacidade de auto-replicar-se e de comandar a síntese de todas as proteínas que compõem um organismo. Tal é o cerne do Dogma Central formulado por Crick em 1958: a unidirecionalidade causal, sempre dos genes para as proteínas, explicação padronizada encontrável em quase toda reportagem de divulgação sobre genética. Há algum tempo, porém, essa imagem simplificadora vem sendo substituída na prática científica por outra, que não faz tábula rasa da embriologia e da biologia do desenvolvimento.

Não é preciso sair do campo da biologia molecular para se dar conta de que o Dogma Central é insuficiente. Antes de mais nada, porque os genes não agem de moto próprio, mas apenas quando ativados por proteínas. No caso da reprodução sexuada, a maquinaria reguladora incorporada ao novo ser pelo óvulo (também portador dos genes maternos) é fundamental para que o DNA comece a ser "lido", ou seja, passe da potência para o ato. Em seguida, a síntese em cascata de proteínas, obviamente já sob a influência do ambiente que circunda o organismo em desenvolvimento, passa a regular quais genes serão expressados, em que tipos de tecidos e em que fase do desenvolvimento, ou situação. Um sem-número de mecanismos de controle e interação são também inerentes ao próprio genoma, como os fenômenos da recombinação, splicing, imprinting e interação gênica.

O desenvolvimento da tecnologia genética se encarregou de explicitar as limitações desse "deeneaísmo", como se poderia batizar a moléstia infantil do reducionismo genético. Esse processo foi reconstruído por Evelyn Fox Keller em seu livro Refiguring Life: "A metáfora-guia do discurso da ação gênica é a dos genes como agentes ativos, capazes não só de animar o organismo mas também de pôr em prática sua construção (...). Essa imagem dupla do gene, em parte o átomo dos físicos, em parte alma platônica, foi imensamente produtiva para geneticistas, tanto técnica quanto politicamente. (...) Inevitavelmente, claro, esse modo de falar sobre genes também teve seus custos, e esses custos se fizeram sentir mais obviamente pelos embriologistas. (...) Ele não deixava nem tempo nem espaço nos quais o restante do organismo, a economia excedente do soma, pudesse exercer seus efeitos" (Keller, 1995: xiv-xv).

Esse "imperialismo genético" parece exercer, entretanto, uma função social e simbólica de maior alcance que a de um mero discurso portátil para lobistas em busca de fundos de pesquisa. Não são poucos os autores - como a 
própria Keller, ou Dorothy Nelkin, Jeremy Rifkin e Richard Lewontin - que o vêem articulado numa constelação política mais ampla e fundamental, que poderia ser resumida na idéia de naturalização do comportamento e das relações sociais, retomando o projeto sociobiológico - agora com a âncora maciça da biologia molecular - demolido numa polêmica feroz dos anos 70 .

Inflada como foi em seu potencial por pesquisadores e jornalistas, a genética se presta a toda sorte de interpretação fundada no exagero. Se é descabido buscar nesse determinismo atenuado as mesmas raízes totalitárias das quais brotou o eugenismo negativo e de massa da primeira metade do século, que alcançou seu paroxismo com o nazismo, não seria um despropósito encontrar nele as sementes de uma nova e mitigada eugenia, positiva e talhada mais para os indivíduos. Em lugar de políticas de Estado voltadas para a melhoria uniformizante de contingentes inteiros de população no futuro, organiza-se o acesso via mercado a um upgrade de saúde e normalidade para os próprios descendentes numa base individual. Esfuma-se, dessa maneira, a distinção tão cara para os pioneiros do Projeto Genoma, como James Watson, entre a eugenia e a genética, definida esta como a atividade científica neutra usurpada, naquela, por "mãos erradas".

Mais que uma possibilidade aberta pela genética, para os militantes do Projeto Genoma a prática que se poderia batizar como ortogenia representa um imperativo de ordem ética. Assim como os entusiastas dos alimentos transgênicos argumentam que contrapor-se a eles é abortar a solução tecnológica para o problema da fome mundial, deixar de pesquisar os meios para desenvolver geneterapias seria um crime de lesa-humanidade. $\mathrm{O}$ aspecto fundamental a reter, aqui, é a invasão de um domínio da vida social antes reservado à interação e à comunicação pelos critérios e procedimentos "objetivos" e "racionais" da tecnociência. O círculo ideológico, se puder ser rompido, só o será por uma problematização do Projeto Genoma na esfera pública, em que a divulgação científica possa oferecer contribuição destacada - embora por enquanto, no Brasil, atue ainda muito timidamente nessa direção.

Uma das raízes da deficiência desse trabalho se encontra na realidade educacional brasileira. O jornalismo científico, por aqui, tem de partir de um patamar muito baixo. Se nos Estados Unidos já é alto o grau de desinformação sobre as bases da genética, a ponto de apenas $21 \%$ de seus cidadãos serem capazes de dar uma definição de DNA (Augustine, 1998:1.640), no Brasil se pode afirmar com segurança que a ignorância científica é ainda mais chocante. Basta mencionar que, segundo pesquisa de opinião do instituto Datafolha realizada com paulistanos poucos dias depois do anúncio da finalização do seqüenciamento do genoma humano (um evento que foi manchete dos principais jornais brasileiros e do mundo), apenas $4 \%$ dos entrevistados souberam definir com alguma correção o que é genoma. Aqui, também, o grau de instrução não melhora muito o quadro de desconhecimento: mesmo entre paulistanos com nível superior de escolaridade, meros $17 \%$ foram capazes de oferecer respostas aceitáveis.

É o caso de perguntar-se, diante desses dados desalentadores, que condições o público brasileiro teria de participar de um debate público sobre a pesquisa genômica, se fosse chamado a isso. Ou, pior ainda, se fosse relegado a acompanhar a distância, impotente e atordoado, um debate tão confuso e fechado quanto tem sido o da regulamentação das culturas transgênicas, que só ultrapassou as paredes acanhadas da CTNBio porque ONGs como o Idec (Instituto Brasileiro de Defesa do Consumidor) decidiram furar o cerco e se dirigir diretamente à opinião pública (sendo por isso tachadas, paradoxalmente, de obscurantistas).

Outro debate que para todos os efeitos não está ocorrendo, ao menos não sob a força detergente da luz do sol, é o do patenteamento de genes humanos relacionados com a gênese e o funcionamento de tumores, seqüências de DNA com provável e alto valor comercial que já começam a ser decifradas por um dos projetos genômicos financiados pela Fapesp (Fundação de Amparo à Pesquisa do Estado de São Paulo) com dinheiro público, o chamado Genoma do Câncer. A lei brasileira proíbe patentes para seres vivos ou suas partes, e muitos pesquisadores são doutrinariamente contrários ao privilégio de invenção para dados da natureza (que podem, assim, ser objetos de descoberta, mas não da invenção pressuposta na idéia de proteção patentária), mas o fato é que essas patentes já estão sendo requeridas por brasileiros no exterior.

A resposta para a questão apresentada acima é óbvia: é mínima a condição do público brasileiro participar, de maneira informada e democrática, de um debate como o dos alimentos transgênicos, ou das implicações da pesquisa genômica. Seria uma falácia, no entanto, concluir que essa constatação diminui, por menos que seja, seu direito de tomar parte nessa discussão. Seria antes o caso de dizer que esse estado de coisas cria uma obrigação para todos os atores do processo, a começar pelos jornalistas: fornecer informação compreensível, qualificada e contextualizada sobre as biotecnologias, da engenharia gené- 
tica à transgenia, da genômica à eugenia. São três os níveis de desafio a serem enfrentados simultaneamente pela divulgação científica, representados por três patamares de ignorância pública acerca dessa força cada vez mais produtiva da realidade social:

- A ignorância de base - É preciso um esforço considerável para esclarecer mesmo os conceitos mais basilares da biologia e da genética, principiando com células, cromossomos, mitose e meiose, etc., pois eles são ignorados mesmo entre intelectuais.

- A ignorância sobre o que está acontecendo - A pesquisa genética é um dos campos mais produtivos da tecnociência, hoje, com publicação copiosa de trabalhos. É fundamental acompanhá-la e cobri-la, jornalisticamente, o que equivale dizer: com critério, hierarquizando e noticiando com destaque somente o que de fato for importante, sem se render ao gene do dia ou da hora.

- A ignorância das implicações - Investigar e expor as conseqüências éticas, jurídicas e sociais das biotecnologias, do monopólio da produção de sementes à patente de seres vivos, da nova eugenia à discriminação genética no emprego e por seguradoras. É talvez a mais complexa de resolver, pois dela padecem até mesmo os jornalistas que cobrem ciência.

Esse desafio triplo está posto para a divulgação científica, mas não só para ela. Especial atenção deveriam ter para com ele as autoridades reguladoras, encarregadas que são de defender o interesse difuso, pois dos interesses particulares da indústria biotecnológica pode cuidar ela mesma. Sem uma intervenção esclarecida e decidida da imprensa e do Estado, a questão da biotecnologia continuará extraviada numa algaravia fundamentalista, e cada vez mais distante do controle social que sobre ela deveria ser exercido.

\section{NOTAS}

E-mail do autor: mleite@post.harvard.edu

Coluna Ciência em Dia: http://www.uol.com.br/folha/pensata/leite.htm

\section{REFERÊNCIAS BIBLIOGRÁFICAS}

AUGUSTINE, N. "What we don't know does hurt us. How scientific illiteracy hobbles society". Science. Washington, AAAS, v.279, mar. 1998, p.1.6401.641 .

EINSIEDEL, E.F. "Cloning and its discontents - a Canadian perspective". Nature Biotechnology. Washington, Nature America Inc., v.18, set. 2000, p.943-944.

GASKELL, G. et alii. "Biotechnology and the European public". Nature Biotechnology. Washington, Nature America Inc., v.18, set. 2000, p.935-938.

HABERMAS, J. “Técnica e ciência enquanto ‘ideologia'”. In: BENJAMIN, W.; HORKHEIMER, M.; ADORNO, T.W.e HABERMAS, J. Textos escolhidos. São Paulo, Abril Cultural, 1980 (Os Pensadores), p.313-343.

KELLER, E.F. Refiguring life. Metaphors of twentieth-century biology. Nova York, Columbia University Press, 1995.

LEITE, M. Os alimentos transgênicos. São Paulo, Publifolha, 2000 (Folha Explica).

. "Os genes da discórdia - Alimentos transgênicos no Brasil". Politica Externa. São Paulo, Paz e Terra, v.8, n.2, set. 1999, p.3-14.

LEWONTIN, R.C. The doctrine of DNA. Biology as ideology. Londres, Penguin, 1993.

NELKIN, D. Selling science. How the press covers science and technology. Nova York, W.H. Freeman, 1995.

PRIEST, S.H. "US public opinion divided over biotechnology?" Nature Biotechnology. Washington, Nature America Inc., v.18, set. 2000, p.939942 .

RIFKIN, J. The biotech century. Harnessing the gene and remaking the world. Nova York, Jeremy P. Tarcher/Putnam, 1998.

WILSON, E.O. Consilience. The unity of knowledge. Nova York, Alfred A.Knopf, 1998. 